\title{
SPORT SPONSORSHIP AS A STRATEGIC TOOL
}

\author{
Diana Komskienè, Kristina Bobinaitė \\ Lithuanian Sports University, Kaunas, Lithuania
}

\section{ANNOTATION}

Sponsorship already achieved the status of an integral part of sport. Nowadays we cannot imagine any sport event or an athlete without a sponsor. Furthermore, it is a big challenge for organizations to attract sponsors. Therefore, it is meaningful to understand that sponsorship is beneficial for both sides. Sponsorship proposals, for sport organizations, can help to achieve investment opportunities for business enterprises. For sponsors themselves, sponsorship can achieve even the most important company goals, such as: access to a new marketplace, increased sales, (which directly will bring the capability of an organization to grow), increased popularity, strengthened image. Nowadays, sponsors are increasingly more strategic in their approach of seeking value from sponsorship opportunities. Furthermore, it is very important to understand how sponsors' decisions might affect all the organization in a strategic prospect. This could take us to a better comprehension of the essential key areas to be considered in the development of sponsorship proposals. We present literature review from this important scientific field which is being followed by the analysis of strategic sport sponsorship. This literature analysis includes objectives of major sponsors and their investments in sports, the scope of sport sponsorship effect on sponsors and implementation of sports sponsorship opportunities into a strategic plan. Research results revealed that sponsorship has changed from a marketing tool to a business platform, where the main principle is to choose the sponsorship project, the conformity of that sponsored project with the business strategy, its goals and target segments. These objectives should be defined by setting long-term periods, which in this case would belong to those strategic goals.

Keywords: sponsorship, sport sponsorship proposal, strategy.

\section{INTRODUCTION}

In recent years, sponsorship has changed from a marketing tool to a business platform where the need for strategic co-operation and mutually beneficial outcomes for both the sponsor and sport property is seemingly more important (Farrelly, 2010). Many of sports sponsorship proposals are counterproductive because of not taking into account the existing relationship between sponsorship and company strategies. The main principle to choose the sponsorship project is the conformity of sponsored project with the business strategy, goals and target segments (Faganel, Bratina, 2013). The strategic work concerns not only the goal setting between two units as such but with the whole system of objects connecting all the units involved to create a consistent whole (Mitchel et al., 2013). It is very important to understand how sponsors' decisions might affect all the organization in a strategic prospect. This could take us to a better comprehension of the key areas to be considered in the development of sponsorship proposals.

The object of the research was to determine the expression of sport sponsorship in strategic planning of sponsors, and the aim was to develop a deeper understanding of how companies use sponsorship as a strategic tool, which is one of the supplements in their marketing program. 


\section{RESEARCH METHODS}

The theory of the article was collected from various sponsorship and strategy literature sources that basically included articles from academic journals. Additional information was obtained from marketing literature. Goal-setting was the first task in the organizational process, which later turned into a clear work task: to define the scope of effect of sport sponsorship on sponsors; to reveal the sports sponsorship opportunities and links between sponsor' strategic planning. The research method was content analyses and systemizing, based upon theoretical framework.

\section{RESEARCH RESULTS AND DISCUSSION}

Scope of sport sponsorship effect on sponsors. For many years sponsorship and sports marketing have been in existence and now have been in the process of great development. Organizers of major events can scarcely expect to receive some funds without expecting to give something back in return.

Sponsorship is often chosen by firms as a communication tool to relay a message about brands, products, or services with prospects (Barez et al., 2007; Gwinner, Bennett, 2008). Sport sponsorship acts as a targeted form of marketing, providing alternatives to larger advertising investments (Brownlee et al., 2012). Cornwell defines sponsorship-linked marketing as the orchestration and implementation of marketing activities for the purpose of building and communicating an association (Lee, Aiken, 2010; Henseler et al., 2013).

Sponsorship supplements classical marketing communication - marcom elements (advertising, public relations, personal selling, promotional selling, and direct selling). It is true that company chooses sponsorship as an alternative marcom element to achieve expected strategic goals, mainly of economic nature, but sponsorship gains importance in comparison with other elements. Advertising becomes expensive, its effectiveness decreases because the target audience is saturated and accepts the messages in a more selective way (Faganel, Bratina, 2013).

The analyses of scientific studies suggests that sponsorship is a communication mix element where a firm provides some financial support to an entity, which may be an individual (e.g. sports), an organization (e.g. a humane society) or a group (e.g. an orchestra), in order to allow this entity to pursue its activities (e.g. a cultural event) and, at the same time establishing a competitive presence globally, facilitating positive brand image from associations that the sponsor utilizes commercially (Čingienė et al., 2013), building attitudes and awareness of the firm's market offerings among consumers (Seguin et al., 2005; Faganel, Bratina, 2013), granting certain agreed direct or indirect benefits (European Sports Conference, 2010), boosting sales and targeting consumers through their lifestyles and interests (Seguin et al., 2005; Barez et al., 2007; Gwinner, Bennett, 2008).

Sponsors convert tangible assets such as cash, product, technology and services into intangible assets such as brand equity and relationships through sport sponsorship, and eventually if the sponsorship program is successful, these intangible assets accrue extensive benefits for corporate sponsors to help cultivate or strengthen corporate competitive advantages and secure long-term survival and development (Seguin et al., 2005; Yang, 2005; Farrelly 2010; Abiodun, 
2011; Faganel, Bratina, 2013; Mitchel et al., 2013). Greater long term benefits may be attainable from a closer, more strategic, network related association with property (Chadwick, Thwaites, 2005).

In summary, it can be stated that sport sponsorship can achieve various strategic and tactical goals that makes impact on the business of the sponsor and affects communicational and economical scope of the sponsor as follows: creates extensive benefits for brand and relationship, fosters favourable brand, company associations and functional congruency, gains publicity and increases public awareness of a brand or company, creates promotional opportunities, offers the target audiences more exceptional way of messages, being in closer network through gained associations strengthens corporate competitive advantages and increases sales.

These can be mentioned as opportunities for sponsors, which can be implemented in strategic planning as analysed in the next section.

Strategic view of sport sponsorship. Ansoff defines strategy as "rules for decisions under partial ignorance" and strategic decisions as "primarily concerned with external, rather than internal, problems of the firm and specifically with selection of the product-mix which the firm will produce and the markets to which it will sell strategy is viewed as a goal-oriented activity closely aligned with long-term outcomes and deliberate planning (Mitchel et al., 2011; Shivakumar, 2014).

The remark that the traditional role of the sales organization in business-to-business marketing is fast developing from a tactical, operational function concerned with the operational putting decision into effect of marketing strategies and programmes, to a strategic capacity focused on the management of the processes that support business strategy, and which plays a growing role in the forming of that strategy (Lane, 2009). Sales function should be involved in marketing strategy creation, and both sales and marketing functions synchronize their strategic and tactical activities to create, deliver, and communicate superior customer value which leads the company to successful strategy creation (Malshe, Sohi, 2009).

Making strategic and neo-strategic decisions develop a better understanding of the firm's capabilities as well as refine the firm's objectives (Shivakumar, 2014). It has been observed that many sponsors refocus their goals in accordance with their evolving view of sponsorship and the market opportunities proposing that, and this changed their expectations of the property. As sponsors detected strategic opportunity (and took bigger risks), they began to view property contribution in a strategic context (Farrelly, 2010). Sponsors are increasingly more strategic in their approach to seeking value from sponsorship opportunities. Large scale sponsorships have even been referred to as strategic alliances or co-branding partnerships (Henseler et al., 2011). Sponsorship became the main source of assets in sport and an excellent promotional activity for companies that sponsor, especially because more and more people are becoming enthusiastic about sport (Faganel, Bratina, 2013). Keeping with a sense of sponsorship as an investment, one opportunity for a corporation would be to form a strategic alliance with a sport or sports. Sport sponsorship provides an opportunity for sport organizations and business corporations to come together (Yang, 2005). Meenagahan reports that the practice of sponsorship is quite developed and has become a standard component of the marketing plan (Faganel, Bratina, 2013). Marketing activities and partnering 
opportunities might still exist without a sponsorship, but sponsorship has the potential to facilitate this process and to increase the overall level and kinds of activity (Yang, 2005) and to enhance multiple stakeholder relations (Henseler et al., 2013; Koc, 2013).

What is now well documented, sponsors have become adept at planning, strategizing and objective setting. For collaboration sponsors extended to joint activity in research, planning, and promotion of the relationship (Farrelly, 2010) and sport sponsorship programmes can be the clue for companies to fulfil their goals implementing opportunities these programs give in strategic planning process. This will be discussed further below.

In planning marketing strategies, a company should consider four key components:

1. Organization situation - what are the firm's goals, capabilities and resources (Lane, 2009; Mitchel et al., 2013). If organization wants to be effective, first of all, it has to set its own goals that depend on firm's resources and capacity. In organizations one of the most important strategic goals are to increase popularity, strengthen the image, achievement on the new market segment et al. This can be reached by involving in one or several of the sponsorship programs. For example, the company can be sponsoring sport events, which can bring these new markets, positioning against competitors and other objectives.

2. Product - market situation - is the product category comparison new to the marketplace, growing, maturing or declining? What are the actual size and expected future growth rate of the product category? (Lane, 2009). In this case organizations who involves in sponsorship, can achieve objectives, based on their product - market situation. Sponsoring can help achieve: new marketplace, increase sales, which directly will bring capability organization to grow. For example, a company involved in sports sponsorships can send instant messages to millions of potential buyers, generate community goodwill part, but most importantly it can increase market share and profit (Bocse et al., 2012).

3. Competitive situation - how many competitors are there? What are their characteristics and marketing method? (Lane, 2009). In recent times, many new opportunities have opened up for companies to compete with one another in creating sponsorship deals that is both favourable to them as well as the sporting entities they get involved with (Sandler, Shani, 1989; Séguin et al., 2005). In other words, if they are not interested and fail to invest in sponsorship, then some of their competitors will, which will eventually lead to a market loss for them in major events like the Olympics, for instance (Seguin et al., 2005).

In essence, sport sponsorship has become a powerful marketing strategy used by firms to communicate with vast external and internal audiences to differentiate themselves from its competitors, with the ultimate goal to orienting consumer's preferences toward sponsors' products (Biscaia et al., 2013). Parker and Fink (2010) contend that once the relationship between team and sponsor is established, the sponsor becomes a member of a tight network of fans. Companies that are able to successfully tap into a consumer's psychological connectedness with a sport team, can become more meaningful to that consumer (Henseler et al., 2013), which makes benefits and extension for brands and relationship. 
4. Environmental situation - What industry-wide and company-specific environmental opportunities and threats are most important (Lane, 2009; Mitchel et al., 2011)? Quinn defines strategic decisions as "those decisions that determine the overall direction of an enterprise and its ultimate viability in light of the unpredictable and the unknowable changes that may occur in its most important surrounding environments." Thus, effective strategic decision making is the product of careful analysis, planning, and implementation (Shivakumar, 2014). This implementation can be made through image building process. It is a two-way street for both the sports entity and the sponsoring organization whereby the latter tends to associate itself or its brands with the positive images obtained by the unique personality of the sporting event (Abiodun, 2011). The advantage of image building, promoted in a long term strategy, lies in the impact it has on an audience - target accurately determined, because of the fittest event (Bocse et al., 2012). Wright found that the association between the sponsor and the sponsored entity (and the activity or event) is long lasting, even when the sponsor withdraws (Faganel, Bratina, 2013).

The summarized sport sponsorship possibilities that can effect sponsor's strategic planning are shown below (Figure).

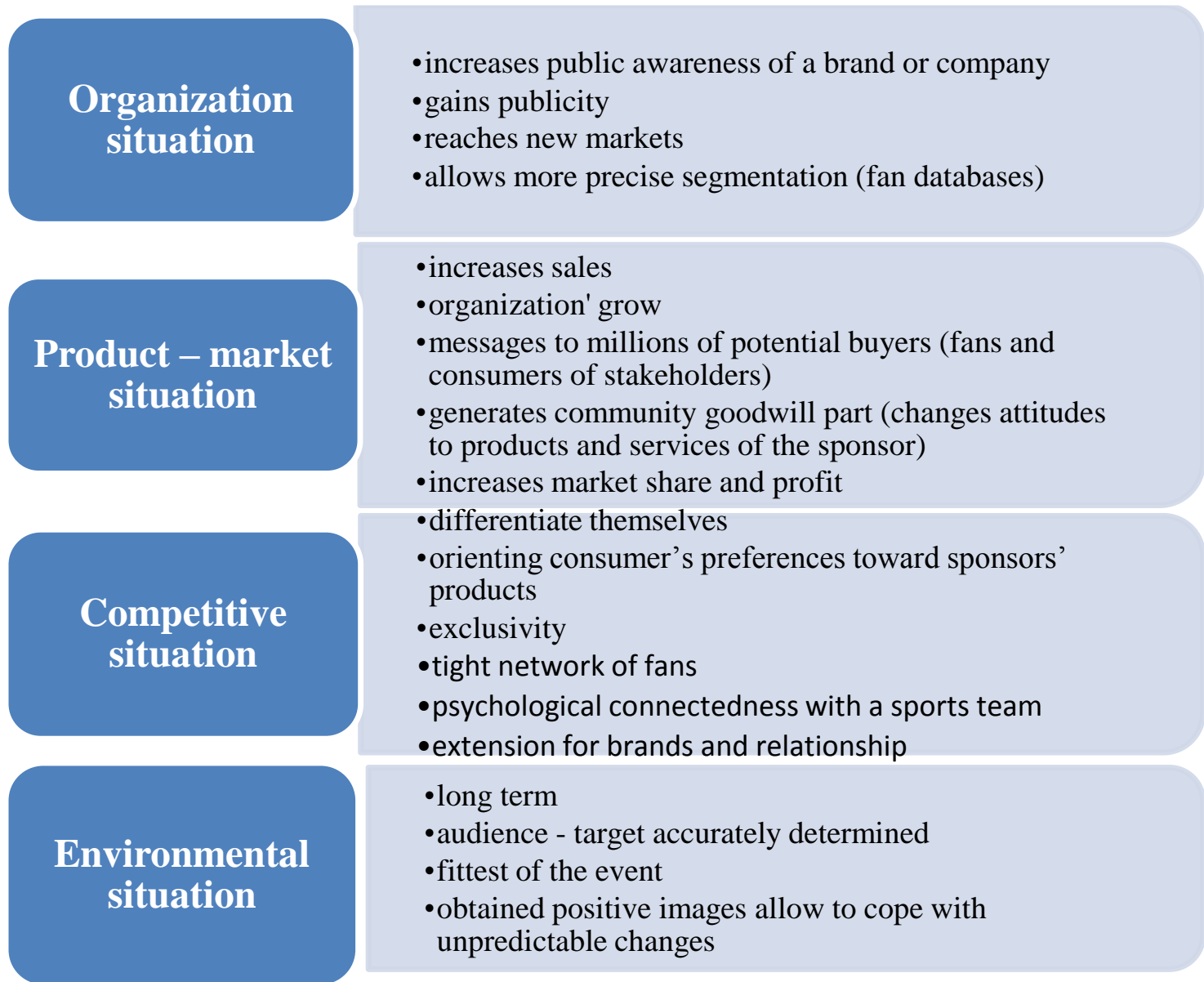

Figure. Implementation of sports sponsorship opportunities into strategic plan of sponsor (by Séguin et al., 2005; Bocse et al., 2012; Biscaia et al., 2013; Mitchel et al., 2013; Lane, 2009; Shivakumar, 2014).

In recent years, sponsorship has changed from a marketing tool to a business platform where the need for strategic co-operation and mutually beneficial outcomes for both the sponsor and sport property is seemingly more important (Farrelly, 2010). The main principle to choose the 
sponsorship project is the conformity of sponsored project with the business strategy, goals and target segments (Faganel, Bratina, 2013).

The strategic work concerns not only the goal setting between two units as such but with the whole system of objects connecting all the units involved to create a consistent whole (Mitchel et al., 2013).

\section{CONCLUSIONS AND PERSPECTIVES}

Sponsorship has changed from a marketing tool to a business platform, where the main principle to choose the sponsorship project is the conformity of sponsored project with the business strategy, goals and target segments. The strategic work concerns the analyses of organizational, product - market, competition and environmental situation, where goal setting between two units as the whole system through sponsorship results into the increase of public awareness of a brand or company, reaching new markets, increase of sales and organizational grow, orienteering consumer's preferences toward sponsors' products, exclusivity, obtained positive images, which allow to cope with unpredictable changes. These are developed in a long term period and can be identified as strategic outcomes attained through sponsorship.

\section{REFERENCES}

1. Abiodun, O. R. (2011). The Significance of Sponsorship as a Marketing Tool in Sport Events. Internet link: 〈http://www.theseus.fi/bitstream/handle/10024/24945/Student_Abiodun_Oladunni.pdf > [Accessed 201409 23].

2. Barez, A., Manion, M. T., Schoepfer, K. L., Cherian, J. (2007). Global cases of effective sports sponsorship: an exploration of a new communications model. Innovative Marketing, 3, Issue 3. Internet link: <http://businessperspectives.org/journals_free/im/2007/im_en_2007_03_Barez.pdf>. [Accessed 201409 23].

3. Biscaia, R., Correia, A., Rosado, A., F., Ross, S., D., Maroco, J. (2013). Sport sponsorship: The relationship between team loyalty, sponsorship awareness, attitude toward the sponsor, and purchase intentions. Journal of Sport Management, 27, 288-302. Internet link: <http://www.humankinetics.com/acucustom/sitename/Documents/DocumentItem/02_Biscaia_JSM_2012013 3-ej.pdf> [Accessed 201409 23].

4. Bocse, R., Fruja, I., Milin, I., A., Merce, I., I., Iosim, I. (2012). General technical issues as promotional sponsorship in sport. Agricultural Management / Lucrari Stiintifice Seria I, Management Agricol, 14(2), 561-566. Internet link:

<http://web.a.ebscohost.com/ehost/pdfviewer/pdfviewer?sid=044198e9-47ac-427b-8f39de463b87e414\%40sessionmgr4004\&vid=11\&hid=4106> [Accessed 201410 10].

5. Brownlee, E. A., Ross, M. B., Shreffler, S. D. (2012). Sponsorship awareness at a new NCAA division I football stadium: An analysis of donation level as a measure of fan identification. Journal of Brand Strategy, 1(4), 413-423. Internet link: <http://web.a.ebscohost.com/ehost/pdfviewer/pdfviewer?sid=20fb3db4-b633-4056-acb1f579ec59e0f3\%40sessionmgr4001\&vid=13\&hid=4109> [Accessed 201409 25].

6. Chadwick, S., Thwaites, D. (2005). Managing sport sponsorship programs: Lessons from a critical assessment of English soccer. Journal of Advertising Research, 45(3), 328-338. Internet link: 
http://web.b.ebscohost.com/ehost/pdfviewer/pdfviewer?sid=2417675d-1c4a-4eb0-b0aa0d7892e968c3\%40sessionmgr114\&vid=10\&hid=128 [Accessed 201410 13].

7. Conference. Contribution of sponsors and trends in sponsorship. Europa Internal Market, Internet link: <http://ec.europa.eu/internal_market/services/docs/sport/conference20100216/7contribution_of_sponsors_and_trends_in_sponsorship_en.pdf> [Accessed 201409 25].

8. Čingienè, V., Komskienė, D., Atraškevičienè, V. (2013). Kas lemia paramos pasiūlymo sporto sektoriuje sėkmę? Paramos pasiūlymo kūrimo teorija ir praktika. Ekonomika ir vadyba: aktualijos ir perspektyvos, 1(29), 166-176. Internet link: <http://vddb.library.lt/fedora/get/LT-eLABa0001:J.04 2013 ISSN_1648-9098.N_1_29.PG_166-176/DS.002.0.01.ARTIC> [Accessed 201409 23].

9. Faganel, A., Bratina, D. (2013). Commercial sponsorship, brand image and WTA tournament. Social Sciences and Humanities International Journal of Academic Research, 5(2), 156-162. Internet link: <http://web.a.ebscohost.com/ehost/pdfviewer/pdfviewer?sid=103a61ea-17fb-4e48-803cc9951dd81629\%40sessionmgr4004\&vid=13\&hid=4104> [Accessed 201410 05].

10. Farrelly, F. (2010). Not playing the game: Why sport sponsorship relationships break down. Journal of Sport Management, 24(3). Internet link: http://web.b.ebscohost.com/ehost/pdfviewer/pdfviewer?sid=4053bb82-7c4a-4713-ad2d6b5e162a8564\%40sessionmgr114\&vid=6\&hid=101 [Accessed 201410 07].

11. Gwinner, K., Bennett, G. (2008). The impact of brand cohesiveness and sport identification on brand fit in a sponsorship context. Journal of Sport Management, 22, 410-426. Internet link: $<$ http://wspahn.camel.ntupes.edu.tw/ezcatfiles/t063/download/attdown/0/BRAND\%20FIT.pdf> [Accessed $20140925]$.

12. Henseler, J., Wilson, B., Westberg, K. (2013). Managers' perceptions of the impact of sport sponsorship on brand equity: Which aspects of the sponsorship matter most? Sport Marketing Quarterly, 20(1), 7-15. Internet link: <http://web.a.ebscohost.com/ehost/pdfviewer/pdfviewer?vid=20\&sid=20fb3db4b633-4056-acb1-f579ec59e0f3\%40sessionmgr4001\&hid=4109> [Accessed 201410 05].

13. Holland, J., Weathers, J. (2013). Aligning a company's people strategy with its business strategy and brand strategy. Journal of Brand Strategy, 2(3), 245-258. Internet link: http://web.b.ebscohost.com/ehost/pdfviewer/pdfviewer?sid=8fe213df-a280-4dc8-99f7eb0d872b6c10\%40sessionmgr111\&vid=9\&hid=101 [Accessed 201410 14].

14. Koc, M. (2013). Sport Sponsorship as a promotional tool: Special focus in albania business-tobusiness (B2B) perspective. Creative \& Knowledge Society, 3(2), 28-38. Internet link: http://web.b.ebscohost.com/ehost/pdfviewer/pdfviewer?vid=8\&sid=4053bb82-7c4a-4713-ad2d6b5e162a8564\%40sessionmgr114\&hid=101 [Accessed 201410 05].

15. Lamont, M., Dowell, R. (2008). A process model of small and medium enterprise sponsorship of regional sport tourism events. Journal of Vacation Marketing, 14(3), 253-266. Internet link: <http://epubs.scu.edu.au/cgi/viewcontent.cgi?article=1148\&context=tourism_pubs> [Accessed 201409 25].

16. Lane, N. (2009). Special issue: Strategic sales and strategic marketing. Journal of Strategic Marketing, 17(3/4), 189-190. Internet link: http://web.b.ebscohost.com/ehost/pdfviewer/pdfviewer?sid=368f1fc7-f11a-4b85-a8979a9f6a5bd9e2\%40sessionmgr112\&vid=15\&hid=124 [Accessed 201409 25]. 
17. Lee, C. W., Aiken, K. D. (2010). Changing brand associations in Taiwan: Nike's sponsorship of high-school basketball. Journal of Sponsorship, 3(3). Internet link:

<http://web.a.ebscohost.com/ehost/pdfviewer/pdfviewer?sid=20fb3db4-b633-4056-acb1f579ec59e0f3\%40sessionmgr4001\&vid=15\&hid=4109> [Accessed 201409 30].

18. Malshe, A., Sohi, R. (2009). Sales buy - in of marketing strategies: Exploration of its nuances, antecedents, and contextual conditions. Journal of Personal Selling \& Sales Management, 29(3), 207-225. Internet link: <http://web.b.ebscohost.com/ehost/pdfviewer/pdfviewer?sid=770fb9e2-4c97-498b-bb76ec5501e7e0fa\%40sessionmgr112\&vid=24\&hid=128> [Accessed 201410 14].

19. Malshe, A., Sohi, R. (2009). What makes strategy making across the sales-marketing interface more successful? Journal of the Academy of Marketing Science, 37(4), 400-421. Internet link: http://web.b.ebscohost.com/ehost/pdfviewer/pdfviewer?sid=8fe213df-a280-4dc8-99f7eb0d872b6c10\%40sessionmgr111\&vid=41\&hid=101 [Accessed 201410 14].

20. Mason, K. (2005). How corporate sport sponsorship impacts consumer behavior. Journal of American Academy of Business, 7(1), 32-35. Internet link:

<http://web.a.ebscohost.com/ehost/pdfviewer/pdfviewer?sid=044198e9-47ac-427b-8f39de463b87e414\%40sessionmgr4004\&vid=13\&hid=4106> [Accessed 201410 10].

21. McKelvey, S., Grady, J. (2008). Sponsorship program protection strategies for special sport events: Are event organizers outmanoeuvring ambush marketers? Journal of Sport Management, 22, 550586. Internet link:

<http://www.humankinetics.com/AcuCustom/Sitename/Dam/067/225_McKelvey_Sponsorship_pr1.pdf> [Accessed 201409 25].

22. Mitchell, F., Nielsen, L., Nørreklit, H., Nørreklit, L. (2013). Scoring strategic performance: A pragmatic constructivist approach to strategic performance measurement. Journal of Management \& Governance, 17(1), 5-34. Internet link:

http://web.a.ebscohost.com/ehost/pdfviewer/pdfviewer?sid=dbae34c7-9a21-4878-91252e1c1830d80b\%40sessionmgr4002\&vid=14\&hid=4209 [Accessed 201410 17].

23. Mitchel, R., Dean, S., Mark, S. (2011). Erratic strategic decisions: When and why managers are inconsistent in strategic decision making. Strategic Management Journal, 32(7), 683-704. Internet link: <http://web.b.ebscohost.com/ehost/detail/detail?vid=77\&sid=8fe213df-a280-4dc8-99f7eb0d872b6c10\%40sessionmgr 111\&hid=101\&bdata=JnNpdGU9ZWhvc3QtbGl2ZQ\%3d\%3d\#db=bth\&AN=60394327> [Accessed $20141015]$.

24. Nikala, L. (2009). Searching for strategy in sales. Journal of Strategic Marketing, 17(3/4), 191197. Internet link: http://web.b.ebscohost.com/ehost/pdfviewer/pdfviewer?sid=8fe213df-a280-4dc8-99f7eb0d872b6c10\%40sessionmgr111\&vid=38\&hid=101 [Accessed 201410 14].

25. Salih, A., Doll, Y. (2013). The Middle Management Perspective on Strategy implementation. International Journal of Business Management, 8(22). Internet link:

http://www.google.lt/url? sa=t\&rct=j\&q=\&esrc=s\&source=web\&cd=3\&ved=0CDsQFjAC\&url=http $\% 3 \mathrm{~A} \% 2$ F\%2Fwww.ccsenet.org\%2Fjournal\%2Findex.php\%2Fijbm\%2Farticle\%2Fdownload\%2F28820\%2F18347\& ei $=$ tCA- 
VNOtHJDpaJaMguAO\&usg=AFQjCNEkyN7uu4B2FzzCQeJobSsZCJbjtA\&sig2=_0QJqQWPSCXhM536E HhNJg\&bvm=bv.77412846,d.d2s [Accessed 201410 15].

26. Seguin, B., Teed, K., O'Reilly, N. (2005). National sports organisations and sponsorship: An identification of best practices. Sport Management and Marketing, 1. Internet link:

<https://www.researchgate.net/publication/237050835_National_sports_organisations_and_sponsorship_an_ identification_of_best_practices> [Accessed 201409 25].

27. Shivakumar, R. (2014). How to tell wich decisions are strategic. California Management Review, 56(3), 78-97. Internet link: http://web.b.ebscohost.com/ehost/pdfviewer/pdfviewer?sid=8fe213dfa280-4dc8-99f7-eb0d872b6c10\%40sessionmgr111\&vid=66\&hid=101 [Accessed 201410 14].

28. Väre, E. (2014). What do sports sponsors really want? The effects of service quality, service value and customer satisfaction on behavioural intentions in sports sponsorship context. International Marketing Management, Internet link:

<http://www.doria.fi/bitstream/handle/10024/98803/What\%20do\%20sports\%20sponsors\%20really\%20want. pdf?sequence=2> [Accessed 201409 29].

29. Wakefield, K. L., Olsen, K. B., Cornwell, B. T. (2007). Spy a sponsor: The effects of sponsorship level, prominence, relatedness and cueing on recall accuracy. Journal of Advertising, 36(4). Internet link: <http://www.tandfonline.com/doi/abs/10.2753/JOA0091-3367360405\#.VCJLixZ0ZQs> [Accessed 201409 25].

30. Yang, X. (2005). Sport sponsorship in China: A strategic investment. Internet link: <https://circle.ubc.ca/bitstream/id/54298/ubc_2005-0344.pdfXINQUAN> [Accessed 201409 25].

31. Zemlickiene, V., Maditinos, D. I. (2012). Marketing strategy formulation for innovative product development process. Business: Theory \& Practice, 13(4), 365-374. Internet link: <http://web.b.ebscohost.com/ehost/pdfviewer/pdfviewer?sid=8fe213df-a280-4dc8-99f7eb0d872b6c10\%40sessionmgr111\&vid=44\&hid=101> [Accessed 201410 14].

\title{
SPORT SPONSORSHIP AS A STRATEGIC TOOL
}

\section{Diana Komskienė, Kristina Bobinaitė}

Lithuanian Sports University, Kaunas, Lithuania

\begin{abstract}
Research background. Sponsorship and sports marketing have been in existence for years and now have been greatly expanded and developed. Organizers of major events can hardly expect to receive some funds without expecting to give something back in return. Historically, sponsorship originated as an inexpensive addition to the marketing mix and was perceived as a philanthropic endeavour. In other words, corporations classified sponsorship as a donation and it was not considered a 'marketing expense', but nowadays it has changed significantly (Abiodun, 2011; Seguin et al., 2005).

The attitude changed with regard to sponsorship when corporations began searching for a return on investment from donations made to various organisations (Meenaghan, 1991; Ramanantsoa, Thiery-Balé, 1989; Wilkinson, 1993). This came after a substantial increase in resources allocated to sponsorship,
\end{abstract}


meaning that sponsorship became increasingly recognised as a valid promotional tool, a business expense that needed justification in the form of Return On Investment (Seguin et al., 2005).

In addition, we have to keep track of constantly changing information. Nowadays, sponsors are increasingly more strategic in their approach to seeking value from sponsorship opportunities. Therefore, it is meaningful to understand that sponsorship is beneficial for both sides. Sponsorship proposals, for sport organizations, can help to achieve investment opportunities for business enterprises. For sponsors themselves, sponsorship can achieve even the most important company goals, such as access to a new marketplace, increased sales, (which directly will bring the capability of an organization to grow), increased popularity, strengthened image. Nowadays, sponsors are increasingly more strategic in their approach of seeking value from sponsorship opportunities. Furthermore, it is very important to understand how sponsors decisions will affect all of the organization in a strategic prospect. This could take us to a better comprehension of the key areas to be considered in the development of sponsorship proposals. Many of sports sponsorship proposals are counterproductive, because not taking into account the existing relationship between sponsorship and companies strategies.

Results and findings. Organization situation is the firm's goals, capabilities and resources. In organizations one of the most important strategic goals is to increase popularity, strengthen the image, achievement on the new market segment resources (Mitchel et al., 2013; Lane, 2009). The company can be sponsoring sport events which can bring new markets to it, positioning against competitors and other objectives. Product - market situation is the product category comparison new to the marketplace, growing, maturing or declining (Lane, 2009). Sponsoring can help achieve new marketplace, increase in sales which directly will bring capability of the organization to grow. A company involved in sports sponsorships can send instant messages to millions of potential buyers, generate community goodwill part, but most importantly it can increase market share and profit (Bocse et al., 2012). Competitive situation is how many competitors there are. What are their characteristics and marketing methods (Lane, 2009)? In essence, sport sponsorship has become a powerful marketing strategy used by firms to communicate with vast external and internal audiences to differentiate themselves from competitors (Cornwell, 2008), with the ultimate goal to orienting consumer's preferences toward sponsors' products (Barros, Silvestre, 2006) (Biscaia et al., 2013). Companies that are able to successfully tap into a consumer's psychological connectedness with a sports team and can become more meaningful to that consumer (Henseler et al., 2011), what makes benefits and extension for brands and relationship. Environmental situation is what industry-wide and company-specific environmental opportunities and threats are most important (Mitchel et al., 2011; Lane, 2009). Quinn defines strategic decisions as "those decisions that determine the overall direction of an enterprise and its ultimate viability in light of the unpredictable and the unknowable changes that may occur in its most important surrounding environments." (Shank, 2009, p. 342). It is a two-way street for both the sports entity and the sponsoring organization whereby the latter, tends to associate itself or its brands with the positive images obtained by the unique personality of the sporting event (Abiodun, 2011). The advantage of image building, promoted in a long term strategy, lies in the impact it has on an audience - target accurately determined because of the fittest event (Bocse et al., 2012).

In our research we define the scope of effect of sport sponsorship on sponsors and reveal the sports sponsorship opportunities and links in sponsors' strategic planning. The research method is content analyses and systemizing based upon theoretical framework.

Keywords: sponsorship, sport sponsorship proposal, strategy. 